\title{
Management Plan for Tailing Slurry at Gold Processing Plant: Case Study Pakay Gold Company Limited
}

\author{
James Obiri-Yeboah \\ Metallurgical Manager, Metallurgy Department, Akroma Gold Company Limited, Nkawkaw, Ghana \\ Email: obirik@yahoo.co.uk
}

How to cite this paper: Obiri-Yeboah, J. (2021). Management Plan for Tailing Slurry at Gold Processing Plant: Case Study Pakay Gold Company Limited. Open Journal of Business and Management, 9, 309-326. https://doi.org/10.4236/ojbm.2021.91017

Received: June 8, 2020

Accepted: January 26, 2021

Published: January 29, 2021

Copyright $\odot 2021$ by author(s) and Scientific Research Publishing Inc. This work is licensed under the Creative Commons Attribution International License (CC BY 4.0).

http://creativecommons.org/licenses/by/4.0/

\begin{abstract}
The resultant disgusting effect related to failure to produce environmental friendly tailing slurry, call for developing a good management plan for tailing slurry production of the newly introduce dry tailing machine at the Gold Processing Plant of Pakay Gold Company Ghana Limited. Hence, the tailing slurry management plan consists of documented steps put together to enhance the discharge of environmentally acceptable tailing product for further monitoring and usage. The nonexistence of a plan for managing input (40\% solid slurry) and output (product) of the tailing filtration plant (dry tailing machine) at Pakay Gold Company is a recipe for systemic disaster which points to the potential of legislative litigation with production and revenue shortfalls. This points out the need for this paper's assessment of plant slurry threats or opportunities, sets an objective for management plan, develops premises and identifies alternatives of the tailing slurry input and product to enhance the development of a plan for managing the dry tailing machine. Furthermore, additional management plan steps that followed were examination and selection of alternative action plan for environmental toxic prevention model. Moreover, plan for implementation as well as supporting plans and review measures were done to eliminate any future legislative agencies litigation. The aim of this paper is to provide tailing slurry management plan that will ensure the eradication of any potential adverse environmental effect and litigation phenomenon that may be associated with the products of the tailing slurry filtration plant.
\end{abstract}

\section{Keywords}

Tailing, Slurry, Filtration, Opportunities, Legislative, Litigation, Toxic, Plan and Alternative 


\section{Introduction}

Tailing slurry is a basic conditioned residual mixture of water (liquid), finely grounded solid and lixiviates (chemicals for solid dissolution) at the final discharge point of a processing plant. Tailings slurry are usually kept on the surface either within retaining structures (Tail slurry Dam) or in the form of heaps (dry stacks) but can also be stored underground in mined out cavities by a process known as backfill (Engels, 2017). Management plan is documented or blueprint for an organization or operational steps to enhance effective execution of day to day duty through well-defined goals for a future direction and determining on the missions and resources to achieve those targets. In other words, management planning process is a step by step guide towards generating a realistic structural plot or proposal to meet set goals after assessment of available resources. Notably, planning is existing in all segments of life endeavors. We need to plan because future is highly uncertain and unpredictable as conditions can change at any point in time. Hence, planning is the basic survival prerequisite of any organization for the growth and success (Community Tool Box, 2018; Bhasin, 2017; Mullane, 2015; Northern Sydney Institute, 2016). Hence tailing slurry management plan is a documented step put together to enhance the discharge of environmentally acceptable conditioned tailing slurry to a designated deposit point for further monitoring and usage with reclamation intention. Lack of tailing slurry management plan at Pakay Processing Plant has provided the bases for encountering the adverse environmental effects of the solid-liquid separation plant (Tailing slurry filtration Plant) that has been introduced at the tailing section of the plant. The aim of this paper is to provide tailing slurry management plan that will ensure the eradication of any potential adverse environmental effect that may be associated with the product of the tailing slurry filtration plant (Dry tailing machine). The paper will also, close the lack of information gap existing in the Ghanaian mining arena regarding the operation of tailing slurry filtration plant. The framework of this paper covers information on tailing slurry composition, tailing slurry filtration plant, detoxification of tailing slurry, quality control test associated with tailing slurry filtration plant product and the plan for managing tailing slurry to meet the environmental requirement for reuse. It is expected that the outcome of this paper would provide the associated legislative agencies with the needed assurance of how environmental friendly, the tailing slurry filtration plant operation will be achieved. Also, the outcome of this research is expected to pave way for eliminating any potential legislative tag of war between the company and the respective governmental agencies with its associated production losses or closure. Therefore, the study will achieve an overall enhancement of production, cost-effectiveness and safe environment.

\section{General Outlook of Pakay Gold Company Limited}

The Pakay Gold mine is located about ten (10) kilometers west of Nkawkaw in 
the Eastern Region of Ghana and is 156 kilometers northwest of Accra, the capital of the Republic of Ghana. The company is registered as joint venture entity with $10 \%$ interest for the government of Ghana as per the current mineral legislation in Ghana. Clearly, the ore deposit of Pakay Gold mine falls into the category of the structurally altered rock deposit. Most of the ore for processing is from the oxidized ore from the orebody in the central mineralization zone. The processing plant capacity is 500 tons per day with working scheme of 330 days per year and service life of 6 years. The Processing plant consists of primary crusher, secondary crusher, primary and secondary mills, thickener, cyanidation carbon-in-leach, desorption (elution unit) and electrowining unit processes for final gold bullion production. Additionally, the Plant has a section for treatment of residual or tailing slurry from the carbon-in-leach section as a unique process in Ghana and laboratory section for daily testing of all the needed levels of the various parameters of unit processes.

The Akroma Gold Company limited is located in the east of Ghana, belonging to Low Mountain and hilly area, higher in north and lower in south with a small inclination. The mine area lies near the equator with yearly average temperature of $25^{\circ} \mathrm{C}$, relative humidity of not more than $75 \%$. The area has two rainy seasons per year (first rainy season is from May to June and the second rainy season is from September to October). Yearly average rainfall is $1200 \mathrm{~mm}$ at the maximum and rainstorm of $104 \mathrm{~mm}$ a day with January to April as dry season every year. The vegetation in the area belongs to half year deciduous forest and regenerative shrubbery and grass among others. The rivers near the mining and processing plant areas are seasonal rivers which are influenced by precipitation considerably. Hence, there is no water in the dry season but the rivers rise in the rain season. Between the mining area and the Processing Plant, there is Odumasua channel with only surface water which is also a seasonal river with its source from Ahantanan. The river course is $2.4 \mathrm{~km}$ long with a catchment of $1.6 \mathrm{~km}^{2}$, a branch of NWI Brook River which is $6 \mathrm{~km}$ from the mine with a flow of $4-3600$ 1/s during rainy season. The residents are mostly farmers with the main crops being: corn, cassava, banana, cocoa and palm (Haigen \& Longzong, 1997). Generally, the outlook of the company depicts a conducive environment for profit maximization if management ensures that workers are given the needed inputs.

\section{Background Information on Tailing Slurry Processing Plant, Detoxification and Quality Evaluations of Tailing Slurry at Pakay Gold Company Limited}

Imperatively, the lack of management plan for tailing slurry input and output product of the tailing filtration plant at Pakay Gold Company is a recipe for ineffective tailing plant operation and legislative tag of war with a closure potential of the company. Lewis (2019) pointed out that management plan allows formalization of management structure and operations with the focus of ensuring that, everyone is on the same page towards the achievement of set goals. Hence, the 
aim of this paper to resolve the legislative tag of war with a closure potential of the company will go a long way to ensure cost-effectiveness towards achievement of the set key performance indicators for the tailing filtration plant at $\mathrm{Pa}$ kay Gold Company. Additionally, the Tailing Slurry Processing Plant at Pakay Gold Company Limited, being the first of its kind in the sub-region, calls for developing a plan for managing the system to enhance efficiency. Consequently, the background information on Tailing Slurry Processing Plant and how the end product can be handled to eliminate associated deficiencies (i.e. detoxification and quality evaluations of tailing slurry) will enhance the achievement of excellent result from this new system.

Innovatively, Tailing Slurry Processing Plant (dry tailing Filter Press or Dry Tailing Machine) at Pakay Gold Company Limited is for the production of dry silt (solid or cake) material as tailing deposit instead of the known usually deposition of slurry in a prepared dam. Currently, dry tailing Filter Press (Dry Tailing Machine) is used at Pakay Processing Plant to separate tailing slurry into relatively dry solid and liquid component. Figure 1 shows dry tailing machine which is fed with slurry of $40 \%-45 \%$ solid, pump through the filter section at pressure of $0.8 \mathrm{kPa}$. Drying of solid in tailing slurry is achieved by Filtration Process at 12 - 14 minutes per batch. At the exit point, about $100 \mathrm{ppm}$ cyanide Filtrate (liquid) and 20\% - 25\% moisture Cake (solid) products are directed into settling pond through filtrate launder and onto a concrete floor respectively. The filtrate product of tailing system is recycled as process water for the plant whiles the cake product is reuse as pit reclamation and construction material after the cyanide level has been tested to be less than 1 ppm (Haigen \& Longzong, 1997).

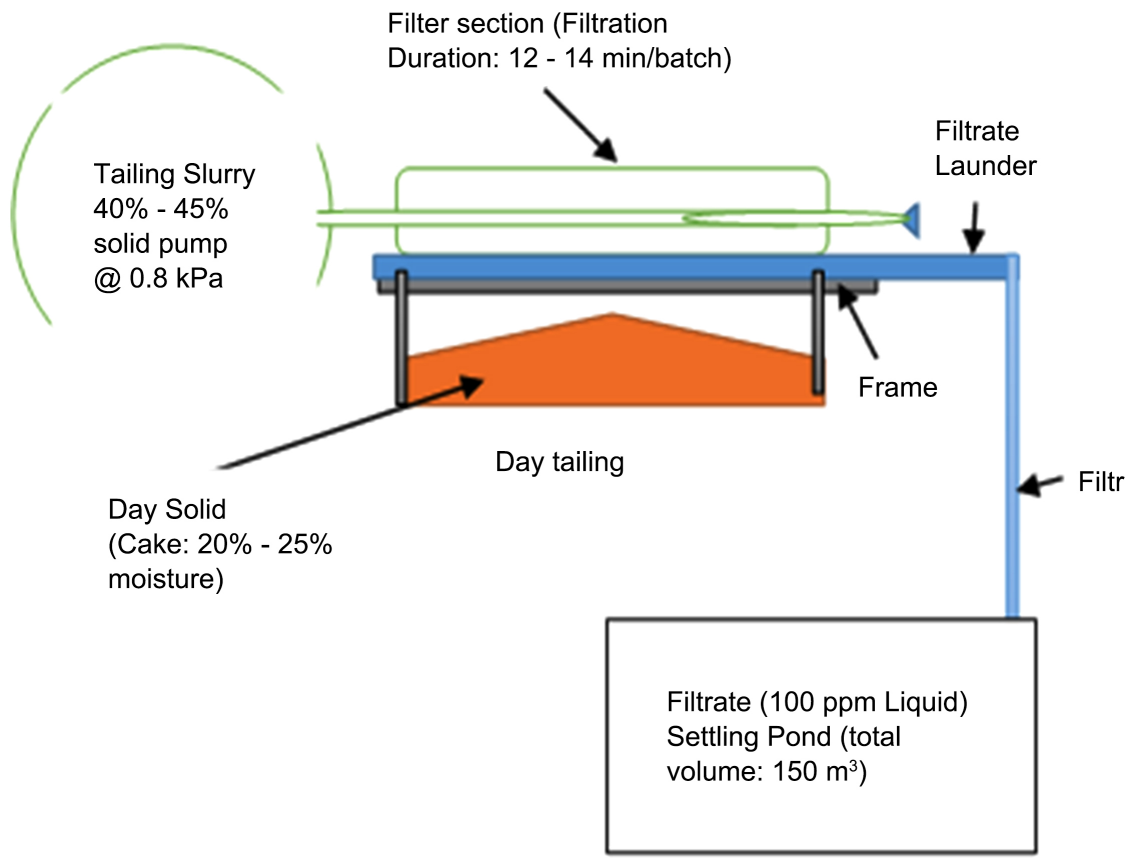

Figure 1. Dry tailing machine. 
Significantly, slurry components (i.e. cyanide as reagent for gold leaching) coupled with slurry dam for tailing deposition effects on the environment are causes of concern to processing plant managers. These concerns are the recipes for the introduction of tailing slurry filtration plant by management of Pakay Gold Company Limited. At the Pakay Gold Company Limited, processing plant cyanide concentration of $200 \mathrm{ppm}$ is added to the slurry in the first two tanks (leaching tanks) which goes through further leaching in additional eight tanks. The eighth tank which is numbered tank 10 with reference to the first leaching tank as tank 1 (one) is the final exit point for the residual slurry from the plant to the tailing slurry filtration plant. Compositionally, the tailing slurry content includes fine ground solid of $95 \%$ passing $74 \mu \mathrm{m}$, lime conditioned water of about $\mathrm{pH} 12$ and cyanide of between 80 to $100 \mathrm{ppm}$. Currently, liquid portion (i.e. cyanide, lime and dissolved minerals solution) of the slurry is recycled through the plant system whiles the solid portion is stored in a dam.

Figure 2 shows slurry production and circulation through the process. This chart starts from the prepared flat land called Run of mine (ROM) pad and cyanide mixing point (i.e. tank) where solid cyanide pebbles are mixed with water at $\mathrm{pH}$ of 12 and pump into the leaching tanks to mix with slurry at the $\mathrm{pH}$ of above 11 from the thickener i.e. a designated tank for reducing liquid content of the slurry to accepted level for leaching). Lime conditioned slurry at the milling stage is fed into the thickener after and classification. This implies the thickener is fed with lime solution from the mill through the classification which then joins the cyanide solution from the cyanide mixing point as thickener underflow which is being pump to the leaching tank. The overflow solution from the thickener is channeled to the mill as addition water and or into tailing dam subject to the dictates of the prevailing conditions. The leaching plant solution exits the tanks through the outlet of tank 10 with the tailing slurry to the tailing plant. At the tailing filtration plant, the solution and the solid cake products are directed to respective destinations. The solution product of the tailing filtration plant is channeled to an area called the tailing solution dam whiles the solid portion is sent to a concrete platform for subsequent conveyance to be reused. The tailing plant solution is sent to the mill through the process storage dam as water for the milling process unit.

Legally, detoxification and quality evaluations of tailing slurry at Pakay Gold Company Limited are to be undertaken as an environmental requirement given by Ghana government legislative agencies. Basically, detoxification is a process of neutralizing or removing poisonous (toxic) properties from a substance or system (Misra et al., 2003). The toxicity of tailing slurry is attributed to its high cyanide, caustic and lime contents. Four general forms of cyanide solution degradation are in use: Natural degradation Chemical oxidation, Precipitation and Biodegradation (Logsdon, Hagelstein, \& Mudder, 1999). Quality assurance is a process or standard followed to achieve the desire results. Additionally, quality control relates to the evaluation of extent to which the set or acceptable standards 


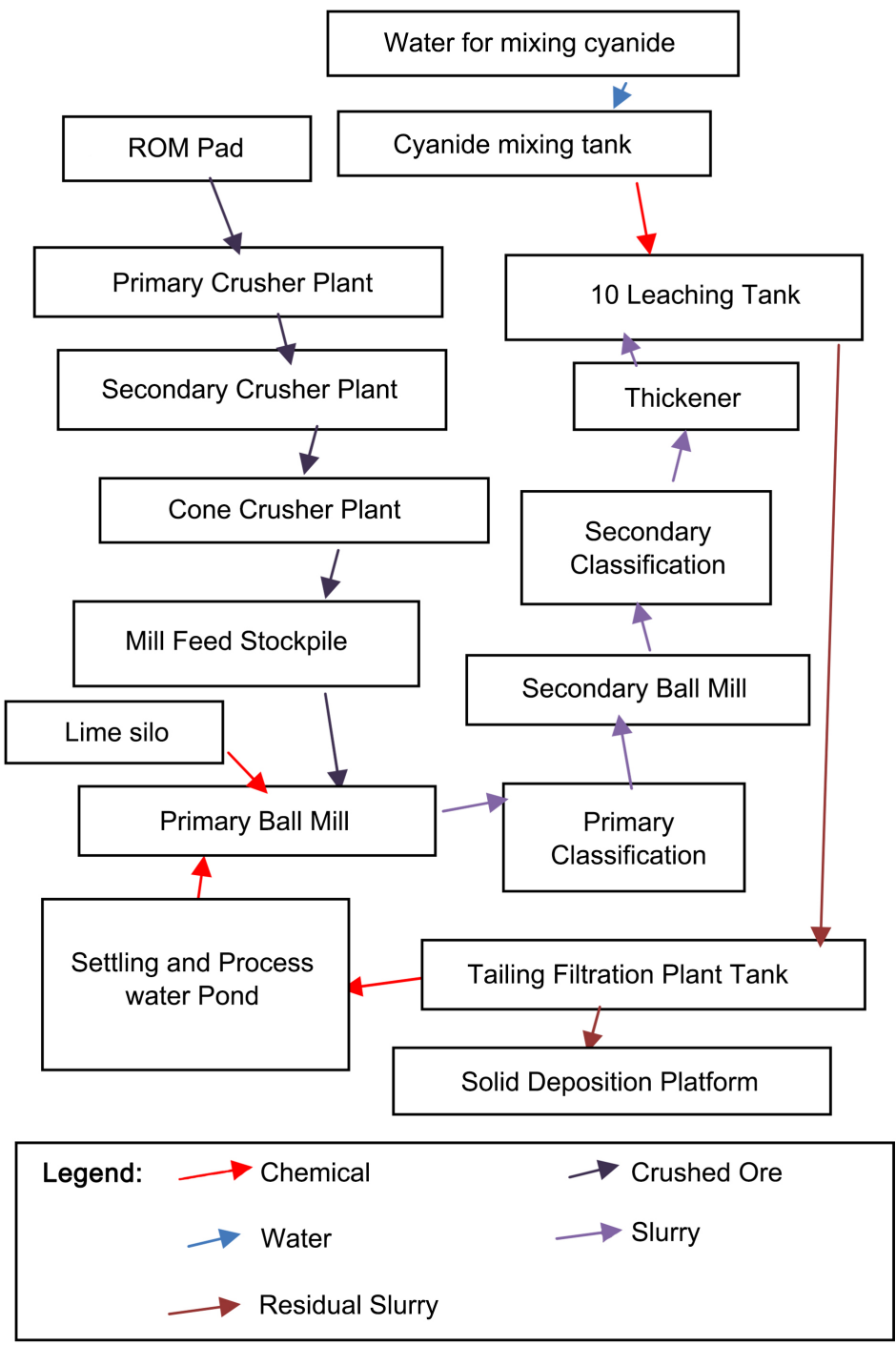

Figure 2. Flow chart of the processing plant for slurry production and circulation.

has been achieved (American Society for Quality, 2019). From Figure 1, the toxic components of slurry or tailing slurry that may come out of the plant, are relatively high levels (i.e. levels are above environmental standard levels as per Table 1) of cyanide, lime and caustic (measured in $\mathrm{pH}$ ). Besides, the moisture content of the solid potion of the slurry should be within the acceptable standard.

Clearly, the plan for detoxification process requires the use of hydrogen peroxide for neutralizing the cyanide and sulpharic acid for neutralizing the high $\mathrm{pH}$ (i.e. from caustic and lime contents) level. Whiles the cyanide has high affinity for oxygen by forming stable complex compound, the high $\mathrm{pH}$ from the caustic and the lime provide suitable condition for effective stability of cyanide reaction with other substances. Logsdon, Hagelstein, \& Mudder, 1999, pointed out that, the most toxic form of cyanide is HCN gas and has very fast-acting poison that is capable of killing a person within minutes if he or she is exposed 
to a sufficiently high dose. Hazardous nature of cyanide, affect not only humans, but also ecological receptors. Three groups of ecological or environmental receptors are of concern in the mining environments are: mammals, reptiles and amphibians, birds and aquatic life. Since the solution potion of the slurry is being recycled, the additives for detoxification process are kept as a standby for emergency situations.

Similarly, the quality evaluations of the slurry in this study relate to measures to obtain filtration products that have levels of toxic components. On the one hand, legislative set standards used for the quality evaluations are the total dissolved solids (TDS), pH level, turbidity level, cyanide concentrations, conductivity, temperature, color, sulphate, arsenic, and calcium and iron concentrations. On the other hand, a new toxic parameter that requires attention is the ground solid (solid cake product of dry tailing plant) moisture levels. This can be handled by adjusting the input parameters for the filtration to meet the legislative set of standards. These filtration parameters are: the amount of water in the slurry, the percentage solid level (i.e. bed level of solid content), air pressure into the filtration system (Filter Press) and the filter cloth frame arrangement for the filtration.

\section{Method Used}

Basically, the lack of plan for managing input slurry and output product of the tailing filtration plant at Pakay Gold Company is a recipe for legislative tag of war that can end up in a closure of the company or production and revenue deficits. Clearly, legislative agencies will be provided with the needed assurance of how environmental friendly, the tailing slurry filtration plant operation will be achieved through presenting effective plan which shows how analytical records of quality control variable can be achieved with reference to legislative or scientific standards. This paper is to provide a combination of operational and tactical plans to support the company's strategic plan of sustainable mining. Systematically, Smith (2019), affirmed the use of judgment based on comparing prevailing variables information and their respective given legislative or scientific standard target for assessment. Consequently, this plan describes steps for redeeming the variance between tailing filtration products and the legislative agency's set standards to enhance pragmatic operational conclusions. Pragmatically, Chanda et al. (2016) portrayed in their paper, a developed management plan as a principal scheme for mitigating the detrimental effects of insecticide resistance.

\section{Result and Discussion}

Essentially, the absence of plan for managing the tailing filtration plant at Pakay Gold Company will lead to litigation that has potential of production and revenue deficits. That is, lack of planning is function of lack of focus which is a recipe for failure in a company's life. Authentically, Olusanya, Awotungase, and Ohadebere (2012) pointed out that effective planning has a relationship with organizational productivity. That is effective planning enhances employee's per- 
formance which is a function of productivity in an organization. Again, Carroll (1993) pointed out that there is copious indication that planning is the most prominent and pervasive of the management functions by indicating that failure in organizations traceable to poor planning or preparation for the future. Hence the study focuses on the operational or tactical plan for managing tailing slurry filtration process to achieve end products that meet legislative agent's (Environmental Protection Agency of Ghana) standard. These standards limits are as shown on Table 1. The Environmental Protection Agency of Ghana limits for companies compliance 6.5 - 9.0, $1500 \mu \mathrm{S} / \mathrm{C}, 500 \mu \mathrm{S} / \mathrm{C}, 75 \mathrm{~N}, 150 \mathrm{Pt}, 250 \mathrm{ppm}, 0.1$ ppm, $0.2 \mathrm{ppm}$ and $1 \mathrm{ppm}$ relates to measurements of $\mathrm{pH}$, conductivity, total dissolved solids, turbidity, color, sulphate $\left(\mathrm{SO}_{4}\right)$, arsenic (AS), free cyanide (CNf) and total cyanide $(\mathrm{CNt})$ respectively. The limits for the respective parameters are the tested limits that are found to be environmental friendly by government's regulatory agency. Hence, per the national legal requirement, companies effluents to the environment are expected to be in compliance to the given limits (i.e. measured levels are not to exceed the given limits) as shown on Table 1.

Therefore, the composition of the plan for managing slurry for the tailing filtration plant focuses on analyzing opportunities (environmental threats) of the slurry, setting objective, developing premises, identifying alternatives, examine alternatives in order to select the needed action plan and formulating plan for implementation. Additionally, review measures will be in place for all levels of the management plan to ensure achievement of the company's set targets.

Primarily, Plant Slurry threats (opportunities) analysis and setting objective for management plan are the main keys for inciting good plan for the slurry treatment at the tailing plant (Bhasin, 2017). Consequently, the focus of Figure 3 of this study (plan) is to identify threats (opportunities) as stand points for setting out activities to provide direction to minimize risk within the Environmental Agency's compliance standards.

Table 1. Environmental protection agency standard parameter limits.

\begin{tabular}{cc}
\hline Standard Parameter & Environmental Protection Agency Limit \\
\hline $\mathrm{pH}$ & $6.5-9.0$ \\
Conductivity EC $(\mu \mathrm{S} / \mathrm{C})$ & 1500.0 \\
Total Dissolved Solids $(\mu \mathrm{S} / \mathrm{C})$ & 500 \\
Turbidity, N & 75 \\
Color, Pt & 150.0 \\
$\mathrm{SO}_{4}, \mathrm{ppm}$ & 250.0 \\
$\mathrm{As}, \mathrm{ppm}$ & 0.1 \\
$\mathrm{~T} . \mathrm{H}, \mathrm{ppm}$ & \\
$\mathrm{CN}_{\mathrm{F}}, \mathrm{ppm}$ & 0.2 \\
$\mathrm{CN}_{\mathrm{t}}, \mathrm{ppm}$ & 1.0 \\
\hline
\end{tabular}




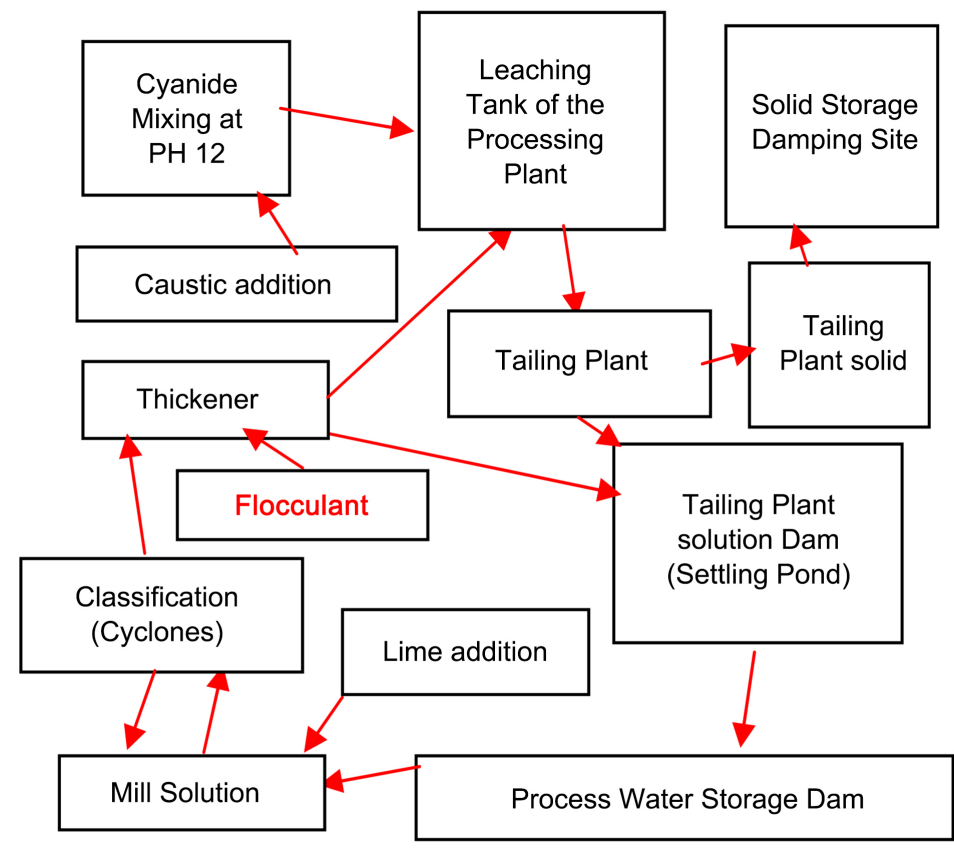

Legend: $\longrightarrow$ Chemical Flow

Figure 3. Solution flow cycle chart for the plant slurry.

It assesses the actual solution and solid components of the slurry to the Tailing filtration plant by taking a realistic look of the regent or chemical requirements of slurry production of the processing plant with aim of extracting gold as the metal of interest. Per Figure 3, the solution flow cycle for the Plant slurry production, shows cyanide mixing in a caustic solution at a $\mathrm{pH}$ greater than 10 . The high $\mathrm{pH}$ level helps to overcome the risk of polluting the environmental air with hydrogen cyanide which can cause fatality to living organisms. The cyanide solution is then added to the lime conditioned slurry from the mill at the leaching tanks section to obtain $80 \mathrm{ppm}$ cyanide concentration level after classification and thickening process. The solution flow chart shows the sequential unit process points of solution as Process water dam, Mill, Classification, Thickener, Leaching tanks and Tailing Plant respectively. At the Tailing Plant, the solution is then filtered into solid with $20 \%$ moisture and $100 \%$ solution (filtrate) in a Tailing Plant Solution Dam to be recycled through the Process Dam. Introduction of lime and caustic conditioned cyanide into the solution flow system are done at the mill and leaching tank respectively. Notably, at the thickener, the concurrent distribution solution through the underflow into the leaching tank and overflow into Tailing Plant solution Dam is enhanced by the addition of flocculant chemical. Similarly, at classification, the solution is concurrently distributed into overflow which is channeled into the thickener and underflow which goes back to the mill. Table 2 shows the monthly average levels of $80 \mathrm{ppm}$ cyanide, $\mathrm{pH}$ of $12 \%$ and $45 \%$ solid of slurry to the tailing section of the Processing 
Table 2. Dry tailing Machine Slurry Parameters for quarter 1 of 2020 production year.

\begin{tabular}{cc}
\hline Standard Parameter & Monthly Average Figures \\
\hline $\mathrm{pH}$ & 12 \\
Slurry Density (\% solid) & 45 \\
$\mathrm{CN}_{\mathrm{F}}, \mathrm{ppm}$ & 80 \\
Filtration Process duration (min/batch) & 14 \\
Feed Slurry Pressure, $(\mathrm{kPa})$ & 0.8 \\
\hline
\end{tabular}

Plant for quarter 1 of 2020 production year. This gives an idea of the chemical composition levels of the slurry which is to be treated (filtered) at the Tailing Filtration plant. Hence, the plan aims at detoxifying both solid and solution to meet the standards set by the Environmental Protection Agency of Ghana.

Additionally, developing premises and identifying alternatives for the slurry management plan will open up the needed legislative requirement and operational factors to enhance understanding among operating members of company's tailing treatment plant. The underlining assumptions of governmental policies on environment and availability of resources for detoxification of slurry to meet the set standard are the cardinals for premise development. Clearly, the measured slurry parameters of cyanide and $\mathrm{pH}$ level (caustic and lime) far exceed the compliance level. It will therefore be suicidal to allow any amount of slurry to find its way to the environment without detoxification. As result, the needed preventive measures such as restraint ponds and recycling of slurry and solution are in place to handle or eradicate where possible any potential danger associated with slurry which is fed to the tailing filtration plant. Currently, ponds such as settling and process water ponds are used as restraint ponds with the solution content being recycled for continuous plant slurry production. Other alternative resources that can be used to handle tailing slurry toxic elements within the compliance limits are; the used of raw water and hydrogen peroxide for tailing slurry dilution and cyanide destruction respectively.

Clearly, Mullane (2015) pointed out the need to evaluate and include alternate course of action as a measure to overcome the destructive effect of any unanticipated event that may throw the laid down plan off track. Hence, evaluations of alternatives toxic prevention modes for the needed action plan selection are done to provide backups for main plan to meet the set target. Invariably, two alternative methods are available for reducing or preventing the toxic properties of tailing slurry from harming the environment at the processing plant. These are the used of settling ponds as raw water for dilution and hydrogen peroxide detoxification of the harmful elements in the tailing slurry. The use of settling ponds as restraint is very good method for keeping the toxic element within the confines of the plant and enhance cost saving by reusing the residual cyanide and $\mathrm{pH}$ level available in the pond solution. However, facilities failure risk and 
unanticipated overflow events can erode the potential gains of the said restraint ponds methods. That is, ponds stand a risk of pumping facility and bonded wall failure can cause pond overflow of toxic solution to the environment. Again, in times of unexpected rainfall is another condition that can also cause pond overflow of toxic solution to the environment. These adverse conditions of ponds have the potential of attracting legislative punishments. Hence, ponds cannot be the sole method for controlling tailing slurry from harming the environment. The possible adversities associated with restraint ponds method, place premium on the inclusion of raw water for dilution and hydrogen peroxide detoxification as alternative course of actions for the tailing management plan of the Processing Plant at Pakay Gold Company Limited.

Notably, the use of raw water for diluting tailing slurry has higher cost-saving potential and effective when the encountered slurry has very low concentration of toxic elements. Conversely, this dilution method has lower potency on harmful element detoxification as compared with hydrogen peroxide detoxification method. It is also a method that is associated with high volume of water wastage. Moreover, the method's lower potency of detoxification points to the relative difficulty of achieving the set legislative compliance levels for the tailing slurry. Hence, the method is good as complimentary method with other effective detoxification models. According to Logsdon, Hagelstein and Mudder (1999), the model for hydrogen peroxide detoxification employ dosing hydrogen peroxide and acid solution at regulated limits into the stream of tailing slurry. This model results in strong oxidation of cyanide into ammonia whiles the acid addition enhances the reduction of the $\mathrm{pH}$ to the compliance limits. The high potency of this model in producing the acceptable compliance limits makes it a better option for detoxifying slurry as compared to any of the methods (i.e. use of settling ponds as restraint and the use of raw water for diluting tailing slurry) available at the Plant. Hence the hydrogen peroxide model for the tailing slurry detoxification is the selected option for action.

Critically, Bhasin (2017) portrayed that the success of every plan hinge on the actions that are taken towards the set target of the business or operation. This place more importance on formulating plan for implementation in this slurry management plan. From the Plant Slurry threats analysis, the major components that require mitigation steps to eradicate their hazardous effect are: Cyanide, high $\mathrm{pH}$ level and the solid. Figure 4 is an implementation plan to mitigate the harmful effects the Tailing Plant Slurry at Pakay Gold Company Limited. Pakay Gold Company Limited, plans to use gold cyanidation practice to extract the gold from the ore and will follow guidelines provided by all the Ghanaian and international legislated agencies on how to handle cyanide from its Procurement vendor, transportation, storage (loading equipment and standard storage shed), use (Facility for Mixing and addition of cyanide into the leaching process), event or emergency pond, compliance check and disposal (detoxification, tailing solid and empty cyanide box) as Figure 4 depicts. 


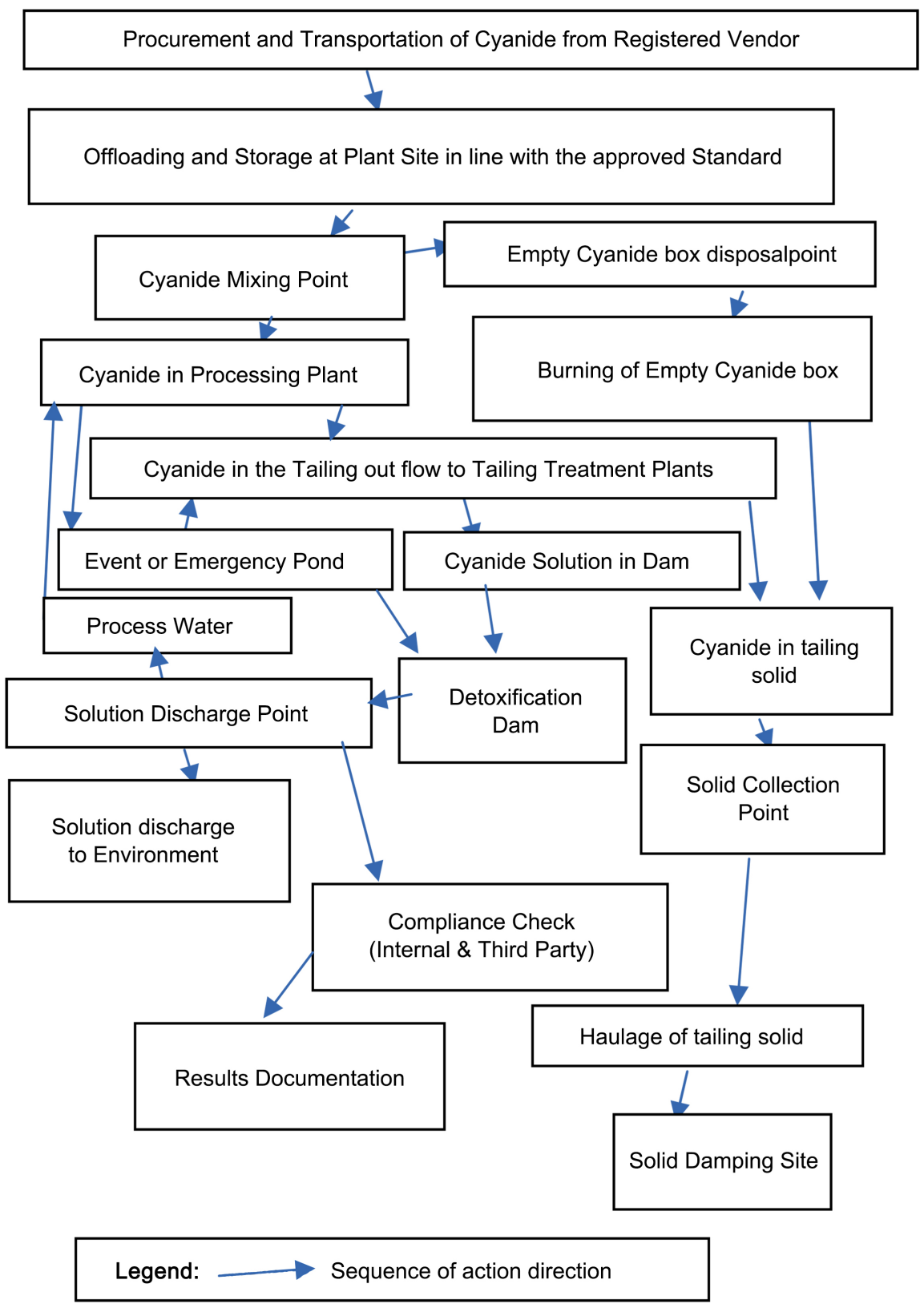

Figure 4. Tailing plant slurry toxic component management flow chart for Pakay gold company limited processing plant.

Procurement and transportation of dry sodium-cyanide briquettes in sealed boxes from legally registered vendor will be conveyed to the mine site in a sealed steel ISO (International Standard Organization) trucks that are waterproof. Transportation of cyanide procedure as spelt out in mining law will be a requirement for vendor's engagement. Loading equipment and a well ventilated storage shed will be provided on site to receive supply of the cyanide product from vendor (Ghana Minerals Commission, 2012). The cyanide will be dissolved into a $\mathrm{pH}$ above 10.5 controlled solution for use in gold extraction under the required safety and environmental standard. Manual control flow rate of 10 
$\mathrm{ml} / \mathrm{min}$ cyanide solution will be transferred to mix with slurry (ore grinded to above $80 \%$ passing $74 \mu \mathrm{m}$ sized grains) in leaching plant. The cyanide will dissolve the gold into a solution, then the gold will be precipitated out of the solution for further extraction.

Emergency ponds for the plant will be provided to meet the mineral and mining regulation standard for containment that is capable to hold maximum operating water balance solution and runoff from a one-in hundred years twenty-fourhour storm event. A cyanide solution dam that will serve as pond (i.e. primary emergency pond) with a capacity of $150 \mathrm{~m}^{3}$ (in conformity with mineral and mining regulation standard for the Plant leaching tank capacity of $135 \mathrm{~m}^{3}$ ) for recycling cyanide solution from the tailing filter press filtrate (solution) to the plant as process water will be provided. Cyanide in tailing solid with compliance point value of less than $1.0 \mathrm{ppm}$ free cyanide will be tested both at plant laboratory and at standard third party laboratory (Ghana Minerals Commission, 2012).

Appropriate operational and environmental monitoring information regarding cyanide and its associate complimentary component will be made available to all legislative stakeholders. The final environmental monitoring program will include schedules, locations, and techniques for cyanide sampling. Primarily, samples will be analyzed at internal laboratory of the Pakay Gold Company. Additionally, a third party analysis of samples will be conducted at an accredited laboratory. Quality Assurance and Quality Control (QA/QC) procedures will be documented for both field and laboratory programs. Results will be reported in accordance with conditions the company's specified chain of command. Disposal of empty cyanide containers and solution to be discharged to the environment will be done after effective detoxification. The Cyanide Code principle related to detoxification and decommissioning of the Pakay Gold Company will be developed and implemented for cyanide facilities to protect communities and the environment. Detoxification of Plant effluent will be directed to a designated pond (detoxification Pond) for the addition of hydrogen peroxide and other auxiliary input in the required amounts to reduce cyanide level to environmentally approved concentration of not more than 1.00ppm free cyanide and $\mathrm{pH} 7$.

Realistically, management planning process does not end after establishing the appropriate course of action. This calls for formulating one or more supportive plans to enhance the main or principal course of action (iEduNote, 2021). The immediate supporting plan for managing the dry tailing will include; procurement of consumable parts for the equipment and training of operating and maintenance teams. Outsourcing of spare part for the dry tailing machine is the cost-effective mode for enhancing management focus on the mission of the business. Therefore, registered outsourcing companies would be mandated to ensure the availability of filter cloth, pump and essential accessories of the dry tailing machine. Additionally, training of the operating and maintenance team as vehicle for smooth operating of tailing machine cannot be overemphasis. This will include training the teams in fields of trouble shooting, identification of key 
performance indicators of the equipment, following the needed safety precautions and collation of the plant's operating report.

Clearly, the implementation of this management plan is expected to come with associated personal and environmental hazards that relate to the operations of dry tailing machine and its end products (Bhasin, 2017). That is, application of the laid down procedures as shown on Table 3 in managing the dry tailing machine will be associated with environmental hazard and personal injury. The prescribe basic personal protective equipment executing the management plan for the dry tailing machine are hand gloves, rubber boots, helmet (hard hat) and safety eye glasses. Additionally, prescribe equipment and chemical for implementing the tailing management plan include a long handle scraper, lubricant table and start-up panel. Table 3 shows the steps to follow as a procedure to handle tailing material. The steps for processing slurry are numerated as 1, 2, 3, 4, 5 and 6 with operational corresponding actions as examining and wear personal protective equipment (PPE), ensuring that the long handle scoop or scraper is in good condition, ensuring the filtration slurry density is not more than $40 \%$ and pressure gauge is on the $0.8 \mathrm{kPa}$, regulating filtration batch between 12 to 14 minute, ensuring the readiness of partner operator and Positioning the filter plate at clearance mode respectively. Concurrently, the resultant potential hazards are utilisation of inappropriate PPE, poor clearing of solid from filter cloth, poor separation of slurry components, poor cake (solid) formation, personal injury and poor solid clearance relating to numerated action of 1, 2, 3, 4, 5 and 6 respectively. Notably, required control measure for actions 1, 2, 3, 4, 5 and 6 are wearing of the prescribed PPE, reporting and requesting for a new scoop, ensuring the effectiveness of slurry pumps, reporting malfunctioning of Filter Press sections, verifying the position of partner and ensuring elimination of friction on the moving parts respectively.

Similarly, from Table 3, procedure numbers of 7, 8, 9, 10, 11 and 12 relate to action steps of ensuring that clean filtrate flow through the discharge launder leading to the settling pond, submerging the flat part of the scraper into the solid on the filter cloth, sampling the solid and the filtrate for internal laboratory test, clearing off all solid on the surface of the filter cloth unto the concrete floor for offloading to Pit, ensuring the good operation condition of standby tailing press and ancillaries are met and solution (Filtrate) and submission product samples to external laboratory for testing respectively. Correspondingly, potential hazards of poor solid cake formation, damage of filter cloth, environmental hazard, poor filtration during subsequent batch and stoppage of plant and production losses relate respectively to action numbers of $7,8,9,10,11$ and 12 . Conspicuously, required control measure for actions $7,8,9,10,11$ and 12 are changing worn-out filter cloths before each batch of filtration, cleaning scraper after every batch, ensuring availability of clean sampling bags and bottles, cleaning of all needed equipments for effective operation, Test run or start all standby equipments and ensuring well labelled samples are available for submission. 
Table 3. Operating procedure for tailing material handling.

\begin{tabular}{|c|c|c|c|}
\hline \multicolumn{4}{|c|}{ Tailing Material Handling } \\
\hline No. & Step & Potential Hazard & Required control \\
\hline 1 & $\begin{array}{c}\text { Examine and wear personal } \\
\text { protective equipment }\end{array}$ & $\begin{array}{c}\text { Utilisation of Inappropriate } \\
\text { PPE }\end{array}$ & Wear the prescribed PPE. \\
\hline 2 & $\begin{array}{l}\text { Ensure that the Long handle } \\
\text { Scoop or scraper is in good } \\
\text { condition }\end{array}$ & $\begin{array}{l}\text { poor clearing of solid } \\
\text { from filter cloth }\end{array}$ & $\begin{array}{l}\text { If the scoop is damaged, } \\
\text { report and request a } \\
\text { new scoop. }\end{array}$ \\
\hline 3 & $\begin{array}{l}\text { Ensure the filtration slurry } \\
\text { density is not more than } \\
40 \% \text { and pressure gauge } \\
\text { is on the } 0.8 \mathrm{kPa}\end{array}$ & $\begin{array}{l}\text { Poor separation of slurry } \\
\text { components }\end{array}$ & $\begin{array}{l}\text { Ensure the slurry Pumps } \\
\text { are effective }\end{array}$ \\
\hline 4 & $\begin{array}{l}\text { Regulate filtration batch } \\
\text { between } 12 \text { to } 14 \text { minute }\end{array}$ & $\begin{array}{l}\text { Poor cake (solid) } \\
\text { formation }\end{array}$ & $\begin{array}{l}\text { Report malfunctioning of } \\
\text { Filter Press sections }\end{array}$ \\
\hline 5 & $\begin{array}{l}\text { Ensure the readiness of } \\
\text { partner operator }\end{array}$ & Personal injury & $\begin{array}{l}\text { Verify the position } \\
\text { of partner }\end{array}$ \\
\hline 6 & $\begin{array}{l}\text { Position the filter plate at } \\
\text { clearance mode }\end{array}$ & Poor solid clearance & $\begin{array}{l}\text { Ensure elimination of friction } \\
\text { on the moving parts }\end{array}$ \\
\hline 7 & $\begin{array}{l}\text { Ensure that clean filtrate } \\
\text { flow through the discharge } \\
\text { launder leading to the } \\
\text { settling pond }\end{array}$ & Poor solid cake formation & $\begin{array}{l}\text { Make sure worn-out filter } \\
\text { cloths are changed before } \\
\text { filtration start }\end{array}$ \\
\hline 8 & $\begin{array}{l}\text { Submerge the flat part of } \\
\text { the scraper into the solid } \\
\text { on the filter cloth }\end{array}$ & Damage of filter cloth & $\begin{array}{l}\text { Clean scraper after } \\
\text { every batch }\end{array}$ \\
\hline 9 & $\begin{array}{l}\text { Sample the solid and the } \\
\text { filtrate for Internal } \\
\text { laboratory test }\end{array}$ & Environmental hazard & $\begin{array}{l}\text { Ensure clean sampling bags } \\
\text { and bottles are available }\end{array}$ \\
\hline 10 & $\begin{array}{l}\text { Clear off all solid on the } \\
\text { surface of the filter cloth } \\
\text { unto the concrete floor } \\
\text { for offloading to Pit }\end{array}$ & $\begin{array}{l}\text { Poor filtration during } \\
\text { subsequent batch }\end{array}$ & $\begin{array}{l}\text { It is good practice to clean } \\
\text { all needed equipments for } \\
\text { effective operation }\end{array}$ \\
\hline 11 & $\begin{array}{l}\text { Ensure the good operation } \\
\text { condition of standby tailing } \\
\text { press and ancillaries are } \\
\text { met and ready to run } \\
\text { when needed }\end{array}$ & $\begin{array}{l}\text { Stoppage of plant and } \\
\text { lost production } \\
\text { Environmental hazard }\end{array}$ & $\begin{array}{l}\text { Test start all standby } \\
\text { equipments that relate to } \\
\text { the operation of standby } \\
\text { tailing Filter press }\end{array}$ \\
\hline 12 & $\begin{array}{l}\text { Solution (Filtrate) and } \\
\text { solid (cake) Sample } \\
\text { submission to external } \\
\text { laboratory for testing }\end{array}$ & $\begin{array}{l}\text { Violation of regulatory } \\
\text { agencies' policies }\end{array}$ & $\begin{array}{l}\text { Ensure well labelled } \\
\text { samples are available } \\
\text { for submission }\end{array}$ \\
\hline
\end{tabular}


Imperatively, reviewing measures are effective way of authenticating the levels achieved in executing a firm's management plan. That is, any action in a plan should be designed so that the people performing the action and the managers who are supervising employees can know whether or not the action taken is realizing the designed objectives (Bhasin, 2017). Hence a team work approach base plan would be employed to assess the measures put in place for managing the dry tailing operations. This implies reviewing of the tailing slurry management plan will include the assessment by operating, supervisory, superintendents and top level management teams. This will enhance effective implementation and review for improvement of the plan and the operation. The operating team will review the daily performance of tailing machine and generate records of the operating parameters during utilization whiles the supervisory team will take care of collation of operators' generated records into a daily report alongside inspection of equipments, assessment of the training and safety needs of operators. That is the supervisory team will undertake effective review by cross checking operator's reported figures with the actual occurrence on the daily operations.

Superintendent team duties regarding the tailing slurry management plan will include reviewing of deviation of the actual occurrence from the set budget for execution of the needed control measures. This will be done by coordinating the daily reports given by supervisors for further reporting to the top management team. Also, superintendents will review and coordinate the budgetary and training needs on the tailing slurry management of all subordinate (i.e. Supervisors and operators) to the top management (i.e. departmental heads the General Manager and Chief Executive Officer) for further review and approval. The review on superintendent reports will be done by top management for final submission to the respective government agencies. The top management team reviews and approves reports given by the superintendent team after the involvement of external auditors to ensure adherence to the management plans and legislative standard in place.

\section{Conclusion}

Principally, the absence of plan for managing input slurry and output product of the tailing filtration plant at Pakay Gold Company is a recipe for lack of formal structure for the operating system. This has the potential of generating production and revenue deficits. Lewis (2019) pointed out that, lack of planning is function of lack of members in a team being on the same page for goal accomplishment. Hence, in order to overcome this prevailing lack of focus, there is the need to write out management plan for the tailing filtration Plant and its products. The paper pointed out the need to assess Plant Slurry threats or opportunities, set an objective for management plan, develop premises and identify alternatives for the slurry management. Furthermore, examination and selection of alternative action plan for environmental toxic prevention model were highlighted in the management plan proposed by this paper. Moreover, this paper 
pointed out the plan for implementation as well as supporting plans alongside review measures as answers to the lack of focus which will lead to eradication of any future litigation with legislative agencies. Conversely, Timmerman (2019), pointed out that, there are unpleasant risk experiences associated with contracting outsource vendor. Therefore, outsourcing critical spare parts coupled with the lack of automation for the dry tailing machine will have a major effect on the sustainability of the output solid product specifications. That is, outsourcing critical components of a plant have the potential of enhancing downtimes with production and revenue shortfalls, if it is not managed well. Similarly, Yeboah and Arthur (2017) emphasized that input slurry percentage solid (i.e. 40\% - 45\% solid) and pressure (i.e. $0.8 \mathrm{kPa}$ ) are the driving forces (factors) of production output qualities (i.e. output solid moisture content and clarity of filtrate produced). Hence, further research work is recommended to ensure that, the introduction of new ideas for spare parts procurement and technological control of tailing slurry feed input (i.e. technological control of tailing slurry of $40 \%-45 \%$ solid input at $0.8 \mathrm{kPa}$ ) enhance operational sustainability.

\section{Conflicts of Interest}

The author declares no conflicts of interest regarding the publication of this paper.

\section{References}

American Society for Quality (2019). Quality Assurance \& Quality Control. https://asq.org/quality-resources/quality-assurance-vs-control

Bhasin, H. (2017). Management Planning Process-All You Should Know. https://www.marketing91.com/management-planning-process/

Carroll, A. B. (1993). Three Types of Management Planning: Making Organizations Work. https://www.questia.com/library/journal/1G1-14442425/three-types-of-management-pl anning-making-organizations

Chanda, E., Thomsen, E. K., Musapa, M., Kamuliwo, M., Brogdon, W. G., Norris, D. E. et al. (2016). An Operational Framework for Insecticide Resistance Management Planning. Emerging Infectious Diseases, 22, 773-779. https://www.ncbi.nlm.nih.gov/pmc/articles/PMC4861508/

Community Tool Box (2018). Developing a Management Plan. https://www.ctb.ku.edu

Engels, J. (2017). What Are Tailings? - Their Nature and Production. http://www.tailings.info/basics/tailings.htm

Ghana Minerals Commission (2012). Minerals and Mining (Health, Safety and Technical) Regulations, 2012. GPCL/A648/350/09/2012. Accra: Ghana Publishing Company Ltd, Assembly Press. http://extwprlegs1.fao.org/docs/pdf/gha168930.pdf

Haigen, L., \& Longzong, Y. (1997). Primary Design for Eassse Gold Mine of Sian Goldfields Limited, Ghana (pp. 4-1-4-23). Lanzhou: Lanzhou Engineering and Research Institute for Non-Ferrous Metallurgy.

iEduNote (2021). Create Effective Plan in 8 Steps (Planning Process). https://www.iedunote.com/create-effective-plan

Lewis, M. R. (2019). How to Write a Management Plan. 
https://www.wikihow.com/Write-a-Management-Plan

Logsdon, M. J., Hagelstein, K., \& Mudder, T. I. (1999). The Management of Cyanide in Gold Extraction (pp. 19-31). Ottawa: International Council on Metals and the Environment. http://www.icme.com

Misra et al. (2003). Cyanide Detoxification Process. https://patentimages.storage.googleapis.com/19/d7/11/f37de07a9833f6/US6551514.pdf

Mullane, T. (2015). The Basic Steps in the Management Planning Process. https://www.linkedin.com/pulse/basic-steps-management-planning-process-terry-mull ane/

Northern Sydney Institute (2016). Manage Operational Plan: Develop Operational Plan Learning Guide.

https://nsfsakai.nthsydney.tafensw.edu.au/access/content/group/0f4ea869-0e76-4936-b 16e-7407f58a3a5d/ManagementAndSmallBusiness/Manage\%20Operational\%20Plan/d ocuments/bsbmgt517_learning_guide_topic_1_v1_36.pdf

Olusanya, S. O., Awotungase, S. A., \& Ohadebere, E. C. (2012). Effective Planning and Organisational Productivity. (A Case Study of Sterling Bank Nigeria Plc). IOSR Journal of Humanities and Social Science, 5, 31-39.

http://www.iosrjournals.org/iosr-jhss/papers/Vol5-issue5/D0553139.pdf https://doi.org/10.9790/0837-0553139

Smith, T. (2019). Qualitative Analysis. Fundamental Analysis. https://www.investopedia.com/terms/q/qualitativeanalysis.asp

Timmerman, J. (2019). Key Elements to a Successful Outsourcing Experience. https://www.devsutd.com/key-elements-to-a-successful-outsourcing-experience/

Yeboah, O., \& Arthur, S. (2017). Expressing Efficiency as a Function of Key Performance Control Parameters: A Case Study of Hydrocyclone Unit Process at Josay Goldfields Limited, Tarkwa, Ghana. Open Journal of Business and Management, 5, 476-486. https://www.scirp.org/journal/paperinformation.aspx?paperid $=77540$ https://doi.org/10.4236/ojbm.2017.53041 